\title{
EVALUATION OF OPERATIONAL RISK MANAGEMENT IN TECHNICAL IMPLEMENTATION UNITS OF MOTOR VEHICLES IN SUPPORTING THE CONTINUATION OF LOGISTIC PATHWAYS IN WEST JAVA
}

\author{
Sumartini, Mokh Adib Sultan, Egi Bhakti Bhuana \\ Manajemen, Universitas Pendidikan Indonesia, Bandung, Indonesia \\ Jln. Dr. Setiabudhi No. 229 Bandung, 40154, Indonesia \\ Corresponding author: sumartini.susanto@gmail.com
}

$\begin{array}{cccc} & \text { Article History: } \\ \text { Received: } 30 \text { Maret } & \text { Revised: } 7 \text { April } & \text { Accepted: } 8 \text { April } & \text { Available online: } 11 \text { April } \\ 2019 & 2019 & & 2019\end{array}$

\begin{abstract}
Risk management is important in supporting all objectives of the West Java Province Motor Vehicle Testing Technical Implementation Unit, namely providing technical safety guarantees for the use of motorized vehicles, trailer trains and postage trains on the road, supporting the realization of environmental sustainability from possible pollution caused by motorized vehicle use. trailer and train carts on the road, and provide public services to the community. Vehicles operated on the road include bus cars, goods cars, articulated cars, train carts, special vehicles and public transportation.

The application of risk management can be used in all fields of work and even in various activities, including decision making, operations, processes, functions, projects, products, services and assets (ISO 31000, 2009). In Indonesia transportation has an important role in supporting national development. Indonesia is an archipelagic country where the development of the transportation sector is designed to support the movement of the economy, national stability and also reduce development inequality between regions by expanding the reach of the distribution of goods and services throughout the archipelago. With the existence of transportation, the economy of the community is more evenly distributed so that it is expected that people's welfare will increase, because the community is easier to get the goods and services needed. One of the important facilities in the land transportation sector is motorized vehicles.
\end{abstract}

Keywords: Environmental, Sustainability, Pollution, Transportation

\section{Introduction}

Risk management has an important role in achieving organizational goals. Efforts to manage uncertainties that can threaten must be dealt with with appropriate approaches and then maintained in a sustainable manner so that every organizational operational goal can be achieved (Wijeratne, Perera, \& De Silva, 2014). Good maintenance and reliability management can improve organizational performance and protect organizational investment (Heizer \& Render, 2015). Good risk management can provide strength for the organization to ensure the continuity of all business processes or objectives of the company. Risk management is an attempt to know, analyze and control risk in each activity with the aim of obtaining higher effectiveness and efficiency (Darmawi, 2005).

Operational risk can be categorized into several factors including, system factors where failure is caused by technology or systems, human factors caused by failure of human resources, external factors where failure is caused by parties outside the organization, and internal factors caused by operational failure of organizational processes ( Muslich, 2007). Risk management 
efforts can be carried out by conducting a risk identification process through several factors, conducting a risk analysis process that is an effort to assess the likelihood and impact of risks, conduct an evaluation process of each risk in accordance with the actual conditions of the organization and the risk handling process using several approaches strategies namely, risk avoidance, risk mitigation, transferring risk and accepting risk (ISO 31000, 2009). The application of risk management can be used in all fields of work and even in various activities, including decision making, operations, processes, functions, projects, products, services and assets (ISO 31000 , 2009). In Indonesia transportation has an important role in supporting national development. Indonesia is an archipelagic country where the development of the transportation sector is designed to support economic movement, national stability and also reduce development inequality between regions by expanding the reach of the distribution of goods and services throughout the archipelago. With the existence of transportation, the economy of the community is more evenly distributed so that it is expected that community welfare will increase, because the community is easier to get the goods and services needed. One of the important facilities in the land transportation sector is motorized vehicles.

In the world of product and service industries, consideration in determining transportation to meet logistical needs is one of the company's main strategies. Transportation activities are important in the movement of products or services from one location to another. The need for the importance of transportation will continue to increase along with the increasing globalization in the supply chain and the growth of e-commerce. Transportation performance will determine Procurement, Production, and Customer Relationship Management performance. Without reliable transportation performance, it can be ascertained that almost all the main activities of the supply chain will not run effectively and efficiently (Zaroni, 2015). Logistics management is planning, implementing and controlling the forward and backward flow efficiently and effectively in the inventory of goods and services related between consecutive origin and consumer points to meet customer needs, while logistics is the position of resources at the right time, in place the right, at the right cost, with the right quality (Riopel, Langevin, \& Campell, 2005). In Indonesia itself is responsible for the field of Transportation, namely the Ministry of Transportation.

One of the functions of the Ministry of Transportation is to formulate and determine policies in the field of service delivery, safety, and transportation security, as well as improving accessibility, connectivity, and capacity of transportation facilities and infrastructure (Network of Legal Documentation and Information of the Ministry of Transportation, 2015). Government efforts in controlling vehicles to be roadworthy are by requiring the testing of the feasibility of motorized vehicles on the types of vehicles of public passenger cars, bus cars, goods cars, trailer trains and attachment trains (Minister of Transportation of the Republic of Indonesia, 2015). This is in line with the Government Regulation of the Republic of Indonesia Number 55 of 2012 where vehicles constitute some of the main elements in the implementation of traffic and road transport which aim to realize road traffic and transportation that is safe, secure, fast, smooth, orderly and orderly, comfortable and efficient, capable of integrating other modes of transportation, reaching all corners of the mainland, supporting equity, growth and stability, driving, driving and supporting national development.

Based on the discussion of Background Problems, the formulas taken include:

1 How is the West Java Office of Transportation of the Motor Vehicle Testing Technical Implementation Unit identifying operational risks?

2 How much is the level of risk in the Motor Vehicle Testing Technical Implementation Unit of the West Java Privinsi Transportation Office?

\section{Literature Review}

\subsection{Operational Management}

Management is a series of activities (including planning, decision making, organizing, leading and controlling) aimed at organizational resources (human, financial, physical and information) with the aim of achieving the goals of the organization effectively and efficiently (Griffin, 2012). Efficient is intended to use resources wisely and in a cost-effective manner, while effective is to implement the right decisions and succeed in their implementation in accordance with the plan.

Operational management is an activity related to the creation of goods and services through a process of transformation from input (input) to outcome (output) (Heizer \& Render, 2015). 
Regardless of whether the final product is an item or service, production activities that take place in the organization often refer to operational or operational management. In that sense, the role of operational management is to manage and implement functions available within the organization including all assets in the organization such as labor, equipment, raw materials, machinery and other factors or functions in the transformation process into goods or services in accordance with the functions and organizational goals. To support the operational management role, a control is needed which serves to ensure that each process can run according to the plan. Every operational process must be evaluated to bring new strategies so that the organization runs more effectively and efficiently. (Anthony \& Govindarajan, 2005).

According to (Heizer \& Render, 2015) operations, marketing, and finance are the three basic functions for all organizations. The operation function creates goods and services. Many advances from management operations were carried out in the 20th century, but from the outset, humans have tried to increase their material existence. Operations management has an important role in an effort to increase productivity. As communities become more prosperous, more resources are devoted to services. In the United State more than $85 \%$ of the workforce is in the service sector. Increased productivity and a sustainable environment are difficult to achieve, but operations managers are the main vehicle for improvement.

\subsection{Productivity}

The creation of goods and services requires converting resources into goods and services. The more efficient in making these changes, the more productive and added value will be in the goods and services. Productivity is the ratio of yield (goods and services) divided by input (resources such as labor and capital). The job of an operations manager is to improve or improve the ratio of results or inputs. Increased productivity means increasing efficiency.

This increase can be achieved in two ways, namely reducing input while keeping results constant or increasing results while keeping input constant. Both of these methods represent an increase in activity. In an economic perspective, the input consists of labor, capital, and management, which is integrated into a production system. Production is the manufacture of goods or services. High production can mean that more people are working and that the level of work is high, but that does not mean high productivity. Productivity measurement is the best way to evaluate a country's ability to provide a better standard of living for its citizens. Only by increasing the productivity of living standards can it be improved (Heizer \& Render, 2015).

There are three variables of productivity including, Labor, Capital, and Management. These three factors are important in increasing productivity. They represent a wider area where managers can take action to increase productivity (Heizer \& Render, 2015).

1. Labor

The increase in the contribution of laborers to productivity is a result of a healthier, more educated, and better-maintained labor force. Some increases are also related to the short working time of the week. About $10 \%$ of the annual increase in productivity is related to an increase in the quality of these workers. Improvement can be found not only through increasing the competence of workers, but also through better utilization of labor with stronger commitments. Strategic strategies such as training, motivation, team building, and human resources, as well as improving education, may be some of the many techniques that contribute to increasing labor productivity. There are several important variables to increase labor productivity among them:

a. Basic education suitable for effective laborers

b. The right amount of labor

c. Additional social expenditures that make workers ready, such as transportation and sanitation

2. Capital

Capital is a tool or other investment used by humans to work or in production activities. Inflaction and taxes increase the cost of capital, making capital investment more expensive. When capital invested in employees whose quality decreases, there will also be a decrease in productivity. Capital investment is sometimes needed, but rarely in sufficient quantities. The trade off between capital and labor is constantly changing. Managers adjust their investment plans with changes in capital and risk costs.

3. Management

Management is a factor of production and an economic resource. Management is responsible for ensuring that labor and capital are used effectively to increase productivity. 
Managers must be able to use technology and knowledge effectively. The more effective use of capital also contributes to productivity. This is the responsibility of the operations manager, as a productivity catalyst.

\subsection{Productivity and Service Sector}

The service sector presents a special challenge to measuring accurate productivity and increasing productivity. The traditional analytical framework of economic theory is primarily based on the activity of producing goods. As a result, much of the economic data is published relating to the production of goods. The productivity of the service sector is difficult to develop, because the nature of work in the service sector has characteristics (Heizer \& Render, 2015), including:

a. Usually requires a lot of labor (for example: counseling, teaching).

b. Usually processed individually (example: investment counseling).

c. Often an intellectual task carried out by a professional (for example: health diagnosis).

d. Often difficult to mechanize and automate (for example: haircut services)

e. The quality is difficult to evaluate (example: the performance of a legal consulting company)

Service company productivity is defined as the ability of service organizations to use imput to offer services with quality in accordance with the expectations of consumers. Dimensions of quantity and quality of services are dimensions that cannot be separated from the service process (Gronroos, 1990). According to Lovelock and Waright (2007) service quality is a customer's longterm cognitive evaluation of the service delivery of a company. In general, services provided by good companies will result in high satisfaction and very high repurchases.

The five dimensions of service quality identified by Parasuraman (in, Subhan, 2006) are:

a. Tangibles, or physical evidence that includes physical facilities (buildings, warehouses and so on), equipment and equipment used (technology), and the appearance of employees.

b. Empathy, which is a condition for caring, having understanding and knowledge of customers, understanding customer needs specifically, and having a comfortable operating time for customers.

c. Reliability, or reliability includes performance must be in accordance with customer expectations which means timeliness, the same service for all customers, sympathetic attitude and high accuracy.

d. Responsiveness, or responsiveness, includes the willingness to help and provide fast (responsive) and appropriate services to customers with clear information.

e. Assurance, or guarantees and knowledge, namely knowledge, courtesy of compensation and the ability of company employees to foster trust in customers to the company

\subsection{Concept of Risk}

Risk management is an attempt to find out, analyze and control risk in each company activity with the aim of obtaining higher effectiveness and efficiency. Therefore it is necessary to first understand the concepts that can provide meaning, broad scope in order to understand the risk management process.

The word risk is widely used in various senses and can be used in everyday conversation by most people. If someone states that there is a risk that must be borne if working on a particular desk, for example: "Motorcycle riding during a rainy season has a high risk of accidents", the risk can be intuitively accepted by the community and the community can take actions or decisions that can satisfy if used in everyday conversation. Economic, statistical and theoretical experts, decision makers have discussed at length about the notion of risk and insecurity, to make the applied risk definition suitable for analysis of analysis in each field of inquiry. Some definitions of risk are presented (Darmawi, 2005):

1. Risk is the chance of loss.

Losses are usually used to indicate a situation where there is an openness to loss or a possible loss. Conversely, if it is adjusted to the terms used in statistics, "Change" is often used to indicate the level of probability that a particular situation will arise. For example, if we throw coins, the probability of a custom image appears at the top after the money arrives on the floor is 0.5 .

2. Risk is the possibility of loss (Risk is the possibility of loss)

The term "Possibility" means that the probability of an event is different between zero and one. This definition is probably very close to the notion of risk that is used daily. However, this definition is not suitable for use in quantitative analysis. 


\section{Risk is uncertainty (Risk is uncertainty)}

Risk is related to uncertainty, which is the risk, because of uncertainty. Uncertainty is subjective and this is what raises risks in decision making.

Statisticians have long defined risk as the degree of deviation from a value around a central position or around the average point. Because the operation of the insurance mechanism is based on probability theory. The definition of risk as an actual deviation from the expected results is actually another version of the definition of "Risk is uncertainty", where relative deviations are a statement of statistical uncertainty.

Another variant of the concept of risk as a deviation is that risk is an objective probability that the actual outcome of an event will be different from the expected outcome. Objective probability is intended as a relative frequency based on scientific calculations. Kuci in this definition is that risk is not the probability of a single event, but the probability of various outcomes that are different than expected.

So from that the term risk can be defined in various ways and each of these definitions contains their respective strengths and weaknesses. Risk is associated with the possibility of unwanted, unexpected or unexpected consequences. In other words, the "possibility" already shows uncertainty. This uncertainty is a condition that causes the growth of risk. And if we examine further "Uncertain conditions" that arise for various reasons, including:

1. Distance time starts planning for activities until the activity ends. The longer the distance the greater the uncertainty.

2. Limited availability of information needed.

3. Limited knowledge or skills or decision-making techniques.

In general, people often equate the notions of Risk, Hazard, and Peril. Indeed, the three terms are closely related to each other. But all three are different, therefore for the purposes of the study these terms must be clearly distinguished. Peril is an event that can cause a loss. Whereas Hazard is a condition and condition that can increase the likelihood of a problem. As a result of this peril will cause one loss or damage to a person or his property both of these terms Peril and Hazard are more closely related to the possibility of occurrence of risks.

\section{Method Research}

The flow of method exposure in this study used a qualitative and quantitative approach. Qualitative analysis is used to describe the possibility and impact of risk in a descriptive or nominal scale. While the quantitative analysis is based on a numerical scale to describe the possibilities and effects of risk. Then the method used is the survey method. Survey method is an investigation that is held to obtain facts from existing symptoms and look for information in fact, both about social, economic, or political institutions from a group or a region. (Nazir, 1988: 65). The survey method in this study is used to describe the existing risk problems to develop operational strategy recommendations to be more effective and efficient.

\subsection{Participants}

In this study participants were divided into two according to the stages of the risk management process, namely risk identification and risk analysis. The number of participants in the risk identification process is five people, while at the risk analysis stage there are fifteen people.

\section{Result and Discussion}

Risk identification is obtained from the results of interviews that have been conducted to several transportation experts as well as examiners of the feasibility of motorized vehicles related to the problem of testing motorized vehicles, as well as the results of the analysis of the Indonesian Republic of Indonesia Law No. 22 of 2009 concerning Road Traffic and Transportation, Regulations Government of the Republic of Indonesia Number 55 of 2012 Concerning the Road Transportation Director General of Transportation in 2005 concerning Motor Vehicle Testing Competence. Then the risk identification results are re-examined so that there is no risk duplication. Then each risk is classified into each factor, namely system factors, human factors, external factors and also internal factors. Results Risk identification consists of failure on internal factors consisting of 10 risks, system or technology factors consisting of 13 risks, human factors consisting of 7 risks and external factors consisting of 8 risks, so in total there are 38 risks that have been identified. Table 4.1 is the result of risk identification. 


\begin{tabular}{|c|c|}
\hline \multicolumn{2}{|r|}{ Risk Identification } \\
\hline \multirow{2}{*}{\multicolumn{2}{|c|}{$\begin{array}{c}\text { Risk } \\
\text { System Factor }\end{array}$}} \\
\hline & \\
\hline 1 & Technology tools that are not up to date \\
\hline 2 & The system is not up to date \\
\hline 3 & The data center has a problem \\
\hline 4 & Power outages \\
\hline 5 & The electricity flow is not stable \\
\hline 6 & Network control issues \\
\hline 7 & The test equipment is not accurate \\
\hline 8 & Maintenance of test equipment and systems is not done regularly \\
\hline 9 & There is no backup test equipment if it is damaged \\
\hline 10 & $\begin{array}{l}\text { Power and telecommunications cables that carry data or information services are not } \\
\text { protected }\end{array}$ \\
\hline 11 & Copy or back up of data is not done regularly \\
\hline 12 & There is no protection against malicious code \\
\hline 13 & There is no policy on software installation \\
\hline \multicolumn{2}{|r|}{ Human Factor } \\
\hline 14 & Data input error \\
\hline 15 & Work accident \\
\hline 16 & Lack of concentration \\
\hline 17 & Employees do not understand the tasks and functions that exist \\
\hline 18 & Less attention to work security \\
\hline 19 & Indifference to system security and or information \\
\hline 20 & Performance evaluation is not conducted regularly \\
\hline \multicolumn{2}{|r|}{ Extrnal Factors } \\
\hline 21 & Lack of awareness of vehicle owners must test to test the vehicle on time \\
\hline 22 & Lack of awareness of vehicle owners towards environmental cleanliness \\
\hline 23 & Damage to office assets due to negligence of vehicle owners \\
\hline 24 & Vehicle owners don't care about driving safety \\
\hline 25 & Fraud of vehicle owners \\
\hline 26 & There are still brokers \\
\hline 27 & Weather is not good \\
\hline 28 & Schedule incompatibility \\
\hline \multicolumn{2}{|r|}{ Internal Factors } \\
\hline 29 & Testing vehicles that do not comply with the SOP \\
\hline 30 & Difficult to find vehicle test equipment spare parts \\
\hline 31 & Procurement of test equipment that is still rare \\
\hline 32 & Inventories of test supporting facilities are exhausted \\
\hline 33 & Generator fuel runs out \\
\hline 34 & The test equipment does not work \\
\hline 35 & Manually checking causes the testing process to take longer \\
\hline 36 & Service requirements for vehicle testing do not meet \\
\hline 37 & $\begin{array}{l}\text { Error during vehicle inspection (Vehicle equipment, lighting system, steering system, US, } \\
\text { tires, rim, frame, vehicle body, brake system, engine, transmission and exhaust emissions) }\end{array}$ \\
\hline 38 & $\begin{array}{l}\text { Administration process errors (Filling in the master card, charging cards and periodic test } \\
\text { books) }\end{array}$ \\
\hline
\end{tabular}




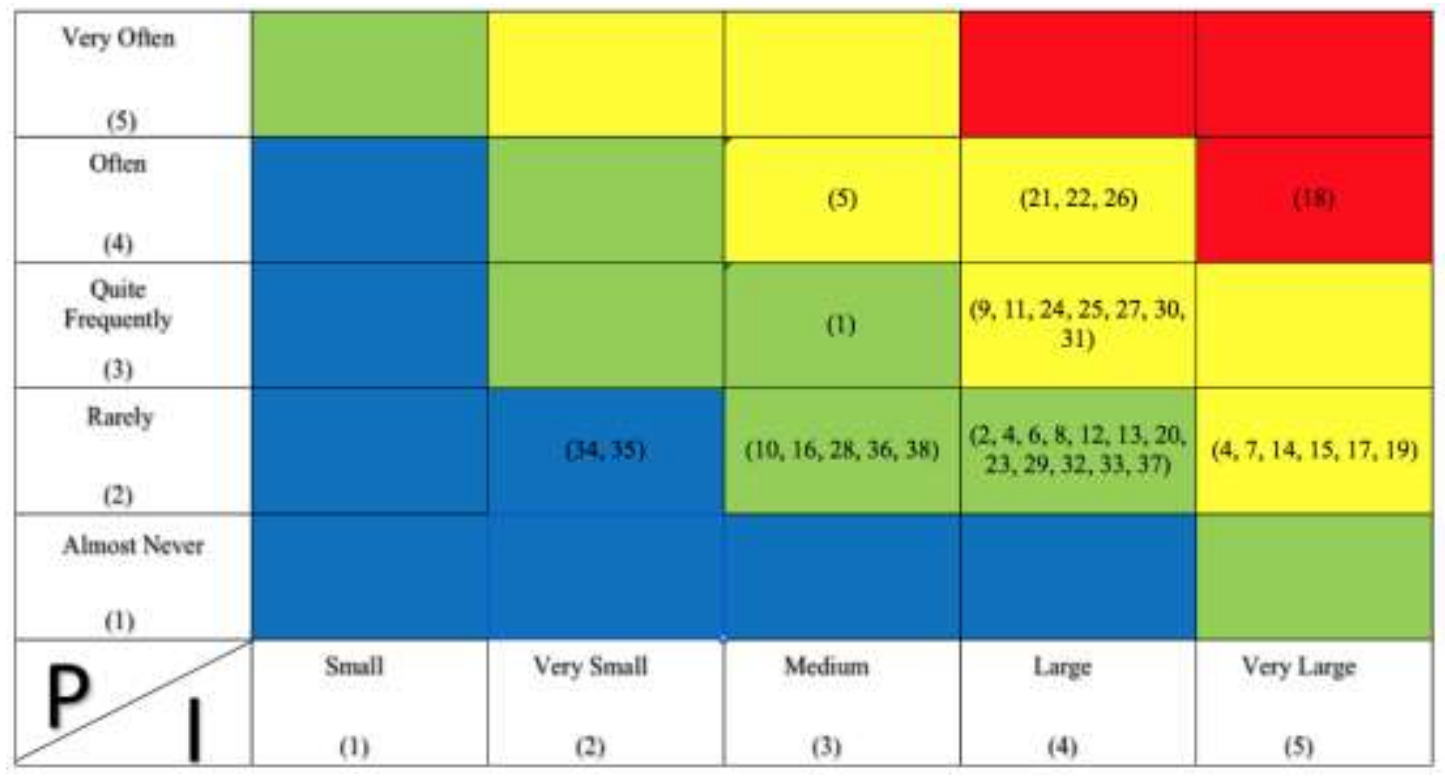

Figure 1 Mapping Possibility and Impact of Risk

Through a risk and impact matrix, it can be concluded that the main priority of handling risk is at the level of "Extreme" risk as much as one risk that is found in human factors, namely "Less attention to job security". The second priority in handling risk is at the level of "High" risk as many as seventeen risks, including consisting of five risks from system factors namely "Electricity outages", "Unstable electricity flow", "Inaccurate test equipment", "No test equipment if damaged "and" Copy or back up of data is not done regularly ". Then in human factors there are four risks that are at the level of "High" risk, namely "Data input error", "Work accident", "Employees lack understanding of existing tasks and functions", and "Indifference to systems and information". Then on external factors there are six risks that are at the level of "High" risk, namely "Lack of awareness of compulsory vehicle owners to test the vehicle on time", "Lack of vehicle owner awareness of environmental cleanliness", "Vehicle owners are less concerned with driving safety" , "Vehicle owner fraud", "There are still brokers" and "Bad weather. Then on internal factors there are two risks which are at the level of "High" risk, namely "Difficult to find vehicle test equipment spare parts" and "Procurement of test equipment that is still rare".

The third priority in handling risk is in the level of "Medium" as many as 20 risks, including consisting of eight risks from system factors, namely "Device technology that is not up to date", "System that is not up to date", "Data centers experience interference" "Network control problems", "Maintenance of test equipment and systems is not carried out periodically", "Power and telecommunications cables that carry unprotected data and information", "There is no protection against Malicious code" and "There is no policy for installing devices soft". Then in human factors there are two risks that are at the level of risk "Medium", namely "Lack of concentration" and "Performance evaluation is not done regularly". Then on external factors there are two risks that are at the level of risk "Medium", namely "Damage to office assets due to negligence of vehicle owners" and "Mismatch schedule". Then on the internal factors there are six risks which are at the "Medium" risk level, namely "Testing vehicles that are not in accordance with the SOP", "Supplies of supporting equipment for testing equipment are exhausted", "Generator fuel runs out" , "Errors during inspection of vehicles (vehicle equipment, lighting system, steering system, US, tires, rim, frame, vehicle body, brake system, engine, transmission and exhaust emissions)" and "Error in administration process (Filling the master card, filling out cards and periodic test books). While the fourth priority of risk handling is at the level of "Low" risk as much as two risks, which comes from internal factors namely "Test equipment does not work" and "Examination manually causes the testing process to be longer".

The application of operational risk management is very important in supporting the achievement of the functions and objectives of the Technical Implementation Unit or Motorized Vehicle Testing Center in West Java. There are four factors of failure in operational risk that can hinder the achievement of the functions and objectives of the UPT or the Testing Center for Motor Vehicles in West Java including, System Factors, Human Factors, External Factors and Internal 
Factors. From the results of the analysis, several risks and risk assessments are obtained, including the following.

From the results of interviews with four experts in the field of transportation and testing of motorized vehicles, the risks identified were 38 types of risks divided into four factors. System factors are 13 risks, human factors are 7 risks, external factors are 8 risks, and internal factors are 10 risks.

Of the 38 types of risks that have been identified, the results of the weight of the probability and risk impact of the questionnaire distributed to fifteen people were obtained, five of which were vehicle testers and administrative officers in the Cimahi City Motorized Test UPT, five vehicle testers and administrative officers in the UPT of West Bandung Regency Motorized Vehicle Testing and five vehicle testers and officers at the Bandung Motor Vehicle Testing Center. The results of the risk assessment are two risks with a "Low" level, eighteen risks with a "Medium" level, seventeen risks with a "High" level and one risk with an "Extreme" level.

\section{Conclusion}

The implementation of operational risk management is very important in supporting the achievement of the functions and objectives of the Technical Implementation Unit or Motorized Vehicle Testing Center in West Java. There are four factors of failure in operational risk that can hinder the achievement of the functions and objectives of the UPT or the Motor Vehicle Testing Center in West Java including, System Factors, Human Factors, External Factors and Internal Factors. From the results of the analysis, several risks and risk assessments were obtained, including the following.

1. From the results of interviews with four experts in the field of transportation and testing of motorized vehicles, the risks identified were 38 types of risks divided into four factors. There are 13 risk system factors, 7 risk human factors, 8 risk external factors, and 10 internal factors.

2. Of the 38 types of risks that have been identified, the results of the weight of the probability and impact of the questionnaire distributed to fifteen people were obtained, five of which were vehicle testers and administrative officers in the Cimahi City Motorized Test UPT, five vehicle testers and administrative officers at the UPT of West Bandung Regency Motorized Vehicle Testing and five vehicle testers and officers at the Bandung Motor Vehicle Testing Center. The results of the risk assessment are two risks with a "Low" level, eighteen risks with a "Medium" level, seventeen risks with a "High" level and one risk with an "Extreme" level.

3. Based on the level of risk, the risk management strategy is divided into four strategies according to the level of risk priority. The efforts that can be done by the UPT or the Motor Vehicle Testing Center are as follows:

a. Risk Acceptance strategies are applied to two types of risks.

b. Risk Reduction is applied to eighteen types of risks.

c. The risk transfer strategy for Third Parties (Risk Sharing) is applied to seventeen types of risk.

d. Risk Avoidance is applied to one type of risk.

\section{References}

Abram , M. (2007). Kajian Manajemen Risiko Operasi Menggunakan Matriks Risiko Berdasarkan Pendekatan Ama (Advanced Measurement Approaches).

Alma, B. (2010). Pengantar Bisnis. Bandung: Alfabeta.

Andalas Clothing. $(2008,1111)$. konveksi-sebagaiu-industri-kreatif-indonesia. Retrieved 11 26, 2015, from www.andalasclothing.com: http://www.andalasclothing.com/11-artikelkonveksi/konveksi-sebagaiu- industri-kreatif-indonesia

Anthony, R. N., \& Govindarajan, V. (2005). Sistem Pengendalian Manajemen (Vol. Edisi 11). Jakarta: Salemba Empat.

AS/NZS 4360. (2004). The Australian And New Zealand Standard on Risk .

Badan Pusat Statistik Jawa Barat. (2015). Statistik Transportasi Jawa Barat. Jawa Barat: Dinas Perhubungan Jawa Barat.

Badan Pusat Statistik Kota Cimahi. (2015). Cimahi Dalam Angka - Cimahi In Figure. Badan Pusat Statistik Kota Cimahi.

Cravens, D. W., \& Piercy, N. F. (2009). Strategic Marketing. New York: McGraw- Hill.

CRMS Indonesia. (n.d.). MONTE CARLO SIMULATION. Retrieved 04 13, 2017, from crmsindonesia.org: http://crmsindonesia.org/monte-carlo-simulation 
CRMS Indonesia. (n.d.). Monte Carlo Simulation. Retrieved 04 13, 2017, from http://crmsindonesia.org: http://crmsindonesia.org/monte-carlo-simulation

Darmawi, H. (2005). Manajemen Risiko. Jakarta: Bumi Aksara.

Dewi, D. (2012). PENERAPAN SISTEM MANAJEMEN RISIKO PADA INDUSTRI NASIONAL SEBAGAI MASUKAN UNTUK PROGRAM PLTN . Prosiding Seminar Nasional Pengembangan Energi Nuklir V, 2012.

Dinas Perhubungan Provinsi Jawa Barat. (2015). Perhubungan Dalam Angka 2015. J awa Barat, Indonesia: Dinas Perhubungan Provinsi Jawa Barat.

Farahani, R. Z., Rezapour , S. , \& Kardar, L. (2011). Logistics Operations and Management Concepts and model. London: Elsevier.

Farid, D., Meybodi , A. R., \& Mirfakhraddiny , S. H. (2010). Investment risk management Tehran Stock Exchange (TSE) using technique of Monte Carlo Simulation (MCS).

Fatmarindah, A. (2010). KAJIAN MANAJEMEN RISIKO OPERASIONAL PADA DIVISI PENERIMAAN, PENIMBUNAN DAN PENYALURAN BBM DI DEPOT UJUNG BERUNG.

Gerbang IImu. (2014, 7 14). Pengertian Produksi dan Penjelasan kegiatan Produksi. Retrieved 12 3, 2015, from www.gerbangilmu.com: http://www.gerbangilmu.com/2014/07/pengertianproduksi-dan- penjelasan.html

Global Association of Risk Professionals \& Badan Sertifikasi Manajemen Risiko . (2008). Sertifikasi Manajemen Risiko Tingkat 1. Jakarta: Badan Sertifikasi Manajemen Risiko.

Gopher Indonesia. (2015, 3 30). Perbedaan antara Produsen, Distributor, dan Agen. Retrieved 12 3, 2015, from id.gopher.co.id: http://id.gopher.co.id/perbedaan- antara-produsendistributor-dan-agen/

Griffin, R. W. (2012). Management (Vol. Eleventh Edition ). USA: South-Western.

Han, Z., Huang, S., Li, H., \& Ren, N. (2016). Risk assessment of digital library information security: a case study .

Heizer, J., \& Render, B. (2015). Manajemen Operasi (Edisi 11 ed.). Jakarta: Selamba Empat.

Heizer, J., \& Render, B. (2015). Manajemen Operasi Manajemen Keberlangsungan dan Rantai Pasokan. Jakarta: Salemba Empat.

ISO 31000. (2009). Risk management - Principles and guidelines. International Standard.

Jaringan Dokumentasi dan Informasi Hukum Kementrian Perhubungan. (2015). Peraturan Presiden Republik Indonesia Nomor 40 Tahun 2015 Tentang Kementrian Perhubungan. Indonesia: Jaringan Dokumentasi dan Informasi Hukum Kementrian Perhubungan.

Kanchu , T., \& Kumar, M. M. (2013). Risk Management in Banking Sector-An Empirical Study .

Kementrian Perhubungan Republik Indonesia. (2012). Peraturan Pemerintah Republik Indonesia Nomor 55 Tahun 2012 Tentang Kendaraan. Indonesia: Kementrian Perhubungan Republik Indonesia.

Ketua Sub Komite Investigasi Kecelakaan LLAJ. (2016). Data Investigasi Tahun 2010-2016 (Database KNKT, 31 Oktober 2016. Jakarta: Kecelakaan LLAJ.

Kusuma, C. (2014, 04 11). PERBANDINGAN COSO ERM-INTEGRATED

Kecelakaan LLAJ Komite Investigasi DENGAN ISO31000: 2009 RISK MANAGEMENT PRINCIPLES AND GUIDELINES. (Associate Researcher CRMS Indonesia ) Retrieved $10 \quad 30, \quad 2016$, from http://www.crmsindonesia.org: http://www.crmsindonesia.org/knowledge/crmsarticles/perbandingan-coso- erm-integrated-framework-dengan-iso31000-2009-riskmanagem

$\mathrm{Li}$, L., Bi , S., \& Sun , Y. (2015). Risk assessment method for aeroengine multiple failure risk using Monte Carlo simulation.

Li, L., Bi, S., \& Sun , Y. (2015). Risk assessment method for aeroengine multiple failure risk using Monte Carlo simulation.

Liputan6.com. (2015, 11 29). Pesanan Innova Baru Nyaris 5.000 Unit. Retrieved $05 \quad$ 18, 2016, from http://otomotif.liputan6.com: http://otomotif.liputan6.com/read/2377222/pesananinnova-baru-nyaris-5000- unit

Manesme , C. O., Barthe'le'my, F., Baroni , M., \& Dupuy, E. (2012). Combining Monte Carlo Simulations and Options to Manage The Risk of Real Estate Portfolios.

Meins , E., \& Sager , D. (2015). Sustainability and risk Combining Monte Carlo s imulation and DCF for Swiss residential buildings. 
Mentri Perhubungan Republik Indonesia. (2015). Peraturan Mentri Perhubungan Republik Indonesia Nomor PM 133 Tahun 2015 Tentang Pengujian Berkala Kendaraan Bermotor. Indonesia: Mentri Perhubungan Republik Indonesia.

Muslich, M. (2007). Manajemen Risiko Operasional Teori \& Praktik. Jakarta: Bumi $\quad$ Aksara.

Nazir. (1988). Metode Penelitian. Jakarta: Ghalia Indonesia.

Peraturan Daerah Kota Cimahi No 18. (2011). Penyelenggaraan Perhubungan.

Peraturan Daerah Kota Cimahi. (2008). Dinas Darah Kota Cimahi.

Riopel, D., Langevin, A., \& Campell, J. (2005). Logistics System: Design and Optimization. United State: Springer.

Riskfacilitator Pty Ltd. (2015). Countries having adopted ISO31000 as an official risk management standard. Retrieved 1030 , 2016, from http://www.riskfacilitator.com: http://www.riskfacilitator.com/countries- having-adopted-iso31000.html

Romli, F., \& Harmin , M. Y. (2015). Use of Monte Carlo method to estimate subsystem redesign risk for complex products: Abstract aircraft redesign case study.

Santoso, T. (2012, 11 17). Risk Management / manajemen risiko Rumah Sakit. Retrieved 1029 , 2016, from http://www.lean-indonesia.com: http://www.leanindonesia.com/2012/11/risk-management-manajemen-risiko-rumah.html

Slack, N., \& Lewis, M. (2008). Operations Strategy.

Tjahjadi, B. (2011). Hubungan Sistem Manajemen Risiko Dengan Ketidakpastian Lingkungan Dan Strategi Serta Dampak Terhadap Kinerja Organisasi .

Wijeratne, W., Perera, B., \& De Silva, L. (2014). Identification and assessment risks in maintenance operations .

Yudha, E. (2010). Pengukuran Indeks Kepuasan Masyarakat Pada Pelayanan Pengujian Kendaraan Bermotor Di Dinas Perhubungan Kota Cimahi. Cimahi: Program Pasca Sarjana Magister Ilmu Pemerintahan Universitas Jenderal Achmad Yani.

Yudistira, M. (2010). Kajian Manajemen Risiko Operasional Ujicoba Budaya Alga Merah.

Zaroni. (2015). Transportasi dalam Rantai Pasok dan Logistik. Retrieved from supplychainindonesia.com: http://supplychainindonesia.com/new/transportasi- dalamrantai-pasok-dan-logistik/ 